Sascha KRAUS - Éva MÁLOVICS

\title{
SMALL BUSINESS STRATEGY: GERMAN AND ANGLO-AMERICAN EVIDENCE
}

This article examines how and to which extent small and medium-sized enterprises (SMEs) apply strategic planning within their business activities. Specifically, the authors address the question of why SMEs seem to plan less than big companies, whether strategic planning and corporate success correlate with each other and whether strategic planning is a function of increasing company size. Along these lines, they conducted an analysis of the relevant literature based on a systematic review of articles on planning and strategy in SMEs over the last twenty years. These have been taken from the leading Entrepreneurship and Strategy journals as well as from other sources in the German as well as the English language science. SMEs seem to plan strategically in a less structured and more informal manner than bigger companies, while they might engage relatively more in (informal) visionary strategic management. The paper structures current research on strategic planning in SMEs and derives an agenda for future research, thereby extending our knowledge on strategic planning in SMEs. The authors close this paper with their own conceptualization of "strategic planning in SMEs".

Keywords: small and medium sized enterprises (SMEs), strategic planning, strategic management

Small and medium-sized enterprises (SMEs) play a major role in the EU economies. They employ more than two thirds of all private sector personnel, and account for more than half of the total revenues (Bauer, 2002). However, these SMEs rarely know or apply modern management methods, above all strategic planning, which can be regarded as particularly beneficial for the corporate success ${ }^{1}$ of SMEs.

Because of the overwhelming success of strategy as a management tool in large companies over the last 20 years, the call for its application in SMEs in rising. This view is confirmed by a number of empirical studies that reveal a link between strategic planning and corporate success (e.g. Rue - Ibrahim, 1998; Bracker et al., 1988; Lyles et al., 1993; Schwenk - Shrader, 1993). However, empirical investigations on the planning/success relationship have not led to consistent results. Scientific publications dealing with strategy in SMEs are still scarce (McCarthy, 2003), especially in the German-speaking countries (i.e. Germany, Switzerland, and Austria).
This article therefore aims at exploring how and to which extent SMEs apply strategic planning within the scope of their business activities. More specifically, we address the question of why SMEs seem to plan less than big companies, whether strategic planning and corporate success correlate with each other and whether strategic planning is a function of increasing company size.

For this purpose, we present a variety of existent empirical studies in order to identify additional determinants and delineate a more complex picture. In doing so, the paper intends to derive the particularities of SMEs regarding their application or lack thereof of strategic planning as well as factors that affect the extent of strategic planning in SMEs. Our paper accordingly contributes to the domain of SME research by structuring current research on strategic planning and deriving an agenda for future research, thereby extending extant knowledge on strategic planning in SMEs.

Building on a literature analysis, we show that present research on strategic planning in SMEs is still 
in its infancy and insufficiently differentiated with respect to enterprise characteristics and from research into larger organizations.

\section{Strategy formulation in SMEs}

\section{Definition of strategy terms}

The strategy development process is closely related to management. In economic terms, strategy can be describes as an approach to reach corporate goals in order to be successful on a long-term basis (e.g. Kreikebaum, 1993). The discipline of strategic management was formed in the 1980s based on advancements in the field of strategic planning. As a general rule, strategic management is regarded as long-term (i.e. at least three years) oriented, directed towards future yield potentials, substantial, holistic, and predominantly associated with top management being responsible for determining the vision, mission, and culture of the company (Haake, 1987; Voigt, 1992). The investigation of young, small enterprises is of special interest in the context of strategic management, since their strategies have to be developed in a highly emergent way, reflecting their fast changing requirements (Mintzberg, 1994).

Conceptually, there are two main types of planning: strategic and operational planning. Operational planning can be described as detailed short-term (one year or less) planning activities for mostly day-to-day operations. It is more specific, less comprehensive, and done at lower level with fewer resources than strategic planning (Robinson et al., 1986).

Strategic planning constitutes the major component of strategic management. In contrast to strategic management, it is not about visionary future concepts, but rather about extrapolating present development tendencies into future. Strategic planning does accordingly not deal with company visions, but moreover with specific guidelines and programs for the achievement of certain goals. The terms strategic planning and longrange planning have often been used interchangeably in the literature.

Strategic planning always includes two sides: the planning process as well as the strategies (content) themselves. According to Porter (1983), a company only has three overall strategies: differentiation (e.g. on quality leadership), focus strategy (concentration on a market niche, a certain customer group, a certain regional market or a certain product and try there to act more effectively and efficiently than their competitors), and cost leadership. Ibrahim (1993) found in an empirical investigation that the niche strategy had been the by far most successful for small enterprises. It can therefore be assumed that young enterprises are particularly successful in a niche, where they can position themselves best against their competition, but at the same time do not get problems with larger enterprises, so that they can finally stabilize on that level (Cooper, 1981).

In the following, the strategy (content) dimension of the strategic planning process in SMEs will not be further investigated.

\section{Characteristics of SMEs}

Before deeper investigating strategic processes within SMEs, it needs to be defined what kind of companies these actually are. There are qualitative and quantitative definitions of SMEs. To the qualitative definitions belongs the one of Noteboom (1994) who regards the following three core characteristics as determining an SME:

1) Small scale,

2) Personality, i.e. the personal influence of an entrepreneur, and

3) Independence of the business, i.e. it is not a subsidiary of a larger holding company.

In the context of this article, we rely on this qualitative, but also on one of the most important quantitative definitions, the one of the European Union (see table 1):

\section{Official EU definition of SMEs (EU Commission 2003)}

\begin{tabular}{|l|l|l|l|l|}
\hline $\begin{array}{c}\text { Enterprise } \\
\text { category }\end{array}$ & \multicolumn{1}{|c|}{$\begin{array}{c}\text { Head- } \\
\text { count }\end{array}$} & Turnover & or & $\begin{array}{c}\text { Balance sheet } \\
\text { total }\end{array}$ \\
\hline medium-sized & $<250$ & $\leq € 50$ million & $\leq € 43$ million \\
\hline small & $<50$ & $\leq € 10$ million & $\leq € 10$ million \\
\hline micro & $<10$ & $\leq € 2$ million & $\leq € 2$ million \\
\hline
\end{tabular}

SMEs have a number of certain characteristics which differentiate them from large-scale companies. So do SMEs tend to offer a more limited range of products on a more limited number of markets and rather use market penetration and product development strategies instead of market development or diversification strategies. Moreover, since SMEs mainly operate in a single or a limited number of markets with a limited number of products or services - often even in a market niche - they usually cannot afford central service departments that are able to conduct complex market analyses and studies (Johnson - Scholes, 1997). In addition, they usually have a lower level of resource, i.e. limited capital (equity, borrowing capacity) and manpower (management and staff), resulting in information 
and skills being insufficient for effective strategic planning (van Horn, 1979). As a result, particularly up to a certain 'critical size', the application of formal planning mechanisms is often missing.

The most important factor for a 'small business owner' is time. Consequently, it has a big influence on the result of any 'activity-optimizing' considerations of the entrepreneur (e.g. Delmar - Shane,

Strategic Planning and Company Success in SMEs

2003). Moreover, the process of strategic decisionmaking in SMEs is often based on experience, intuition or simply on guessing (Welter, 2003). These arguments entail unique problems but also opportunities for strategy development in SMEs (see table 2) (Füglistaller $e t$ al., 2003):

Table 2

Characteristics of SMEs and resulting problems and opportunities

\begin{tabular}{|l|l|}
\hline \multicolumn{1}{|c|}{ Problems } & \multicolumn{1}{c|}{ Opportunities } \\
\hline $\begin{array}{l}\text { Limited resources, time and } \\
\text { means }\end{array}$ & $\begin{array}{l}\text { High customer proximity } \\
\text { High market knowledge }\end{array}$ \\
Limited know-how and & Strong influence by the \\
methodological knowledge & entrepreneur (engine of \\
Focus mainly on only one & change) \\
market or product & High identification and \\
Potential overload for & motivation of employees \\
management & Quick implementation possible \\
\hline
\end{tabular}

Despite their relatively small market power, SMEs' small size and flexibility permits them to specialize in narrow niches that are generally uninteresting for big companies due to the relatively small sales volumes and their high fixed costs. In addition, SMEs' limited resources result in a concentration on a small product range where strong competitive advantages and specific problem-solving competencies can be built up, for instance, with regard to qualitative market leadership. Also, higher decision flexibility and direct customer contacts are particularly helpful for the conversion of $\mathrm{R}-\mathrm{D}$ results into marketable innovations, although risks remain in terms of over-dependency on only a few products and the resulting lack of loss compensation (Kropfberger, 1986).

The presented unique characteristics of SMEs are likely to impact on the design of strategic planning in SMEs which, in turn, is considered to affect corporate success (see fig. 1).

\section{Strategy in SMEs}

Most strategic management techniques are considered to be irrespective of company size. However, SMEs often have particular resource disadvantages which can hinder successful implementation of strategic actions, e.g. in terms of human or financial capital. Thus, the application of formal strategic planning is often missing in SMEs, especially when they are still below a certain 'critical (company) size' (Karagozoglu - Lindell, 1998).

One major reason therefore is that many decisionmakers in SMEs is the entrepreneurs' attitude towards strategic instruments. Often, they are convinced that strategic planning is a waste of time. Rather, it is assumed that they use their limited resources more effectively for day-to-day or sales operations. Additionally, they often regard formal strategic planning as being only applicable to large enterprises and/or bureaucratic organizations, and thus to be non-transferable to the requirements of the fast-moving and flexibly structured SMEs.

From the entrepreneur's perspective, three major objections are expressed against the use of strategic processes in SMEs (Füglistaller et al., 2003; Esser et al., 1985; Martin, 1979):

1) Strategic measures and instruments constrain flexibility and the ability for improvisation;

2) It makes more sense to use the limited time resources for operational or sales activities or $\mathrm{R}-\mathrm{D}$ rather than for strategy-formulation processes;

3) Strategic management is too bureaucratic.

Refusing to use strategic planning can be explained by various reasons (Scharpe, 1992; Robinson - Pearce, 1984), such as:

- Insufficient knowledge,

- Distrust,

- Personal over-estimation as well as refusal of external assistance, 
- Tradition-based thinking,

- Fear of radical change,

- Fear of loss of flexibility, restriction of scope of action, high costs,

- Lack of time or overload for management.

\section{Previous research on strategic planning in SMEs}

\section{Methodology}

The literature analysis is based on a comprehensive review of articles dealing with planning/strategy in SMEs in the leading Anglo-American Entrepreneurship journals, Entrepreneurship Theory and Practice, Journal of Business Venturing, Journal of Small Business Management, and Small Business Economics ${ }^{2}$, the leading Strategy journals, Strategic Management Journal and Long Range Planning, over the last twenty years as well as the leading German-language contributions in this field.

By selecting two of the largest language areas worldwide (English is the premier language in business and trade in the world, and German the most spoken and important language in Europe), we think to be able to deliver results which are representative for a huge overall population.

By focusing on the most relevant journals, we believe to have chosen an adequate basis for classifying the different strands of literature in both language areas. Since the German-language science publish its results still rather in books than in journals (e.g. in form of Ph.D. dissertations, habilitations, or research reports), these sources have furthermore been included to our search. ${ }^{3}$

Over the last two decades, several empirical studies from both these language areas have concentrated on strategic planning in SMEs. The number of identified scientific studies explicitly dealing with strategic planning and its relation to corporate success in SMEs is 26. The studies have been found in the following sources (see table 3):

The majority of respective articles $(42.3 \%)$ have been published in Entrepreneurship journals, i.e. journals explicitly dealing with small businesses and their characteristics. This position is followed by the General Managements journals as well as books/dissertations (which are most of the German language sources) with $19.2 \%$ each, Strategy journals with $11.5 \%$, and "others" with $7.6 \%$.

Although the studies differ in terms of focus and scope, which makes a direct comparison difficult, they offer a wide array of interesting partial results that are specified subsequently. More specifically, we will first

Table 3

Sources for the literature review

\begin{tabular}{|l|c|c|}
\hline \multicolumn{1}{|c|}{ Bibliographic source } & $\begin{array}{c}\text { No. of } \\
\text { studies } \\
\text { included }\end{array}$ & $\begin{array}{c}\text { Total } \\
(\mathbf{\%})\end{array}$ \\
\hline Entrepreneurship Journals & 11 & 42.3 \\
\hline General Management Journals & 5 & 19.2 \\
\hline Books, Dissertations etc. & 5 & 19.2 \\
\hline Strategy Journals & 3 & 11.5 \\
\hline $\begin{array}{l}\text { Others (chapter in edited books, working } \\
\text { papers, conference proceedings, etc.) }\end{array}$ & 2 & 7.6 \\
\hline Total number of studies & $\mathbf{2 6}$ & $\mathbf{1 0 0 \%}$ \\
\hline
\end{tabular}

examine the share of SMEs that plan strategically and address the question of which individuals are most likely to initiate planning activities. Subsequently, we present evidence on the link between strategic planning and success and finally discuss findings with regard to the effect of company size.

\section{The extent of strategic planning in SMEs}

For the German-speaking countries, the following picture concerning strategic planning in SMEs arises: In their survey of 214 German industrial enterprises Esser et al. (1985) found that instruments of strategic planning are most frequently applied in the legal form of a limited company $(\mathrm{GmbH})$ and public limited company (respectively incorporated) (AG). Additionally, the results show a positive correlation between a company's workforce size and the likelihood of the use of strategic planning activities. Based on an analysis of 1,461 German industrial enterprises, Scholz (1991) identified a rate of $73 \%$ of SMEs indicating to plan strategically.

The results from Austria and Switzerland look even more disillusioning. Kropfberger (1986) revealed in a survey of 161 medium-sized enterprises in Austria (mainly from the consumer and capital goods industry) that nearly half of the interviewed enterprises only plan on a short-term basis and that almost one third does not have any sales planning at all. Similarly, according to a survey of 107 SMEs by Fröhlich - Pichler (1988), almost one quarter of the investigated enterprises do not apply any planning, about one third only use shortterm and another third long-term planning, and only $12 \%$ use strategic planning. More than one decade later, Leitner (2001) presented a somewhat improved situation: Out of 100 Austrian SMEs from different industries $62 \%$ had established a written corporate policy. Nevertheless, the strategy formulation still seems to take place, to a large extent, intuitively $(31 \%)$ or due to experience $(88 \%)$. A recent study from Austria on 
468 young SMEs shows that less than $40 \%$ of the interviewed companies had developed a business plan for their enterprise six years after start-up. The study also showed that strategic instruments, such as SWOT or portfolio analysis, balanced scorecard etc. are hardly known and therefore also not applied in enterprises of this kind (Kraus, 2006).

An almost identical picture shows up in Switzerland, where Haake (1987) surveyed 127 SMEs from different industries: $27.9 \%$ of the investigated enterprises apply no written planning, $31.4 \%$ only short-term planning, $26.9 \%$ long-term and finally $13.7 \%$ strategic planning

Although the English-language studies differ more in terms of their research focus, the results look similar: In a study by Lyles et al. (1993), 71 out of 188 examined SME owners reported to possess formal plans with a time frame of at least three years. In another study by Naffziger - Kuratko (1991), even 96 of 115 surveyed SME owners indicated to formally plan and set functional goals.

More recently, various studies have shown that SMEs do embark on planning activities, although often only intuitively or on a less sophisticated level. It seems likely to assume that top management is exclusively responsible for the development of plans in SMEs, as is demonstrated in an investigation by Naffziger - Mueller (1999) with 71 U.S. enterprises. Also, Bracker - Pearson (1986) stress the importance of the entrepreneur's influence on strategic planning.

The view that better trained or educated entrepreneurs are more likely to think and act strategically is well established (e.g. Beutel, 1988). Gibson and Cassar (2002), for instance, discovered in their study of Australian SMEs in the year 2002 that enterprise leaders with university degrees plan more frequently than others. Whether these characteristics, in turn, positively correlate with corporate growth and success is not clear. In addition, the study revealed that for economic graduate founders the probability for the existence of a business plan is higher than for those of other degrees.

\section{The strategic planning/success relationship}

Firm performance is a key issue in strategic planning, referring to the firm's success in the market. Several researches have thus tried to discover the factors responsible for firm success and failure (e.g. Lussier Pfeifer, 2000; Duchesneau - Gartner, 1990). There is a wide range of measure of organizational performance. Although there is no universally accepted definition of success, most studies refer to the firm's financial performance. However, on the most general level, the primary goal of the firm is (long-term) survival (Simon,
1996). Hence, success can have different forms for different people, e.g. survival, profitability, ROI, turnover or employee growth, reputation etc. (Vesper, 1980). The main goals for small enterprises can also be other than financial, and they can change over time (Gray, 1992 ,). It has been argued that for measuring success in small firms, survival and growth may be the most appropriate measures (Pasanen, 2003).

Berman et al. (1997) demonstrate that strategically planning enterprises achieve better firm performance, i.e. higher financial results. This implies that expenditures related to planning activities would be compensated financially. This hypothesis was confirmed empirically several times. For example, Schwenk - Shrader (1993) showed in their meta-analysis of 14 studies that the existence of strategic planning is significantly positively correlated with (financial) success of the enterprise. Similar results were derived by Robinson - Pearce (1984) in an earlier meta-analysis, Bracker - Pearson (1986) in an analysis of small enterprises in the cleaning industry, Sexton - Van Auken (1982) based on the investigation of 357 small enterprises from Texas, Bracker et al. (1988) in a study of 217 managers of small electronics firms, and Orpen (1985) who examined 58 managers of small enterprises. Furthermore, Matthews - Scott (1995) are convinced that planning activities can be helpful to reduce the level of uncertainty in the company. Schwenk - Shrader (1993) come furthermore to the conclusion that strategic planning promotes longterm thinking, reduces the focus on operational details, and provides a structure for the identification and evaluation of strategic alternatives. Based on an analysis of 51 small enterprises in the U.S., Robinson et al. (1984) show that simple planning activities can already have a positive influence on the success of small enterprises. Furthermore, the process of (formal) planning itself already seems to have a positive effect in that it leads to a better understanding of the business and to a broader range of strategic alternatives (Lyles et al., 1993).

Empirical studies also demonstrate that formal strategic planning (e.g. based on business plans) can be helpful for young and fast growing enterprises (Castrogiovanni, 1996; Robinson et al., 1984). For example, Sexton - Van Auken (1985) found in a longitudinal analysis that the survival rates of SMEs conducting formal strategic planning are higher.

\section{Strategic Planning and Company Size}

According to Haake (1987), there is a link between company size (independent of whether it is measured based on total capital, revenues, or number of employees) and the use of strategic instruments. Robinson $e t$ 
$a l$. (1984) also indicate that type and degree of formality of planning are dependent on the company's development stage. Matthews - Scott (1995) even state that formalization is the most common dimension of strategic planning. The formalization increases, according to their results, with increasing enterprise growth since bigger enterprises possess more resources and internal differentiation. This reasoning entails the notion that smaller companies possess fewer resources in terms of time, personnel or knowledge and will thus carry out less (formalized) planning activities (Robinson - Pearce, 1984).

Risseeuw - Masurel (1994) confirm their hypothesis that planning activities will intensify with increasing enterprise growth in their study of 1,211 real estate agents in the Netherlands. In addition, they show that big enterprises plan more intensively than small ones. However, the authors emphasize that young enterprises tend to undertake more planning particularly in the start-up phase in order to raise external financial capital.

\section{Discussion}

Despite the fact that small and big enterprises differ considerably in size and type of resources, it has been shown that decision-makers of SMEs do apply planning, although in many cases rather intuitively and/ or informally. It often occurs (at least sub- or unconsciously) as a sign of strategic thinking (Ohmae, 1982). Therefore, it remains to be seen whether SMEs do not plan 'strategically' at all or whether they just do not plan 'in a formal way'.

Along these lines, Welter (2003) states that not only strategic planning itself but especially the quality of planning plays an important role. Planning in SMEs seems to be rather unstructured, sporadic, incremental and often not formalized. This suggests a rather systemic type of thinking in the entrepreneur/entrepreneurial team which might be imprinted on the organization for years to come. The actual process of decision-making that can be observed in reality often deviates substantially from the ideal picture of rationality. To relate this to our initial definitions of strategic management and planning, in this process, entrepreneurs might engage too much in (informal) strategic management as vision development while neglecting bread and butter planning.

Although there is no question that an able entrepreneur can achieve success without any planning at all, it seems reasonable to assume that each form of planning, whether it is conscious or unconscious, formal or informal, can at least help to facilitate corporate success.
Planning can provide an essential means to developing a thorough understanding of a company's expected results, alternatives, and opportunities. An effective strategic planning for SMEs system should therefore provide a logical basis for thinking, but also be practical, workable, and able to grow together with the company (Martin, 1979).

The implementation of strategic planning, therefore, seems to be favorable independent of company size, although in practice a positive relationship between increasing company size and the implementation of strategic management instruments can be measured (Haake, 1987). This finding is likely to be correlated with - if not caused by - the increasing need for uncertainty reduction about the enterprise's role in its environment, an increasing attention to ever more similar details and ability to cope with matters in a 'mechanistic' fashion. Nevertheless, Moyer (1982) is convinced that enterprises regardless of their size are capable of executing the most important functions of strategic planning.

Building on these notions, it can be assumed that people in most SMEs think strategically. A conscious or formal strategic process, however, mostly takes place in the head of a very limited number of employees. Due to the well accepted view that strategies limit an SME's scope of activity too much, thereby reducing its flexibility, many SMEs are still lacking written strategic plans (Pleitner, 1986).

In this regard, Gibb - Scott (1985) are of the opinion that strategic awareness and the involvement of the entrepreneur offsets the lack of formal strategic planning as an output of strategic management. The degree of the entrepreneur's strategic orientation thus seems to be a key factor for the strategic focus of the enterprise (Mazzarol, 2003). In that respect, it can be reckoned that an open-minded orientation positively affects the production of strategic plans (Riquelme, 2000). Accordingly, the role of the entrepreneur and his attitude towards concepts of strategic planning are often critical in SMEs for their implementation. Planning is an activity without direct returns, which is hard to justify (psychologically), either if customers are flocking to the company or if they are hard to come by and marketing and sales activities appear more important. It seems, therefore, that the central question is not whether strategic planning in SMEs is fruitful, but for which groups of SMEs and under which circumstances it is worthwhile. A possible avenue for future research could thus focus on identifying different configurations of clusters of comparable enterprises with particular strategic needs over the life time of industrial and organizational development (Reschke - Kraus, 2005). 
Since the link between the use of strategic instruments and corporate success seems to be also prevalent in SMEs, it is essential to foster a respective awareness in the enterprise. Since SMEs are rarely small-sized big enterprises, the existing concepts and instruments have to be adapted accordingly (Kraus et al., 2005). It appears doubtful to develop 'standard' strategies and instruments that are equally effective in big companies and SMEs. As the use of strategic planning also seems to be worthwhile in SMEs, the respective instruments have to be aligned with the personnel as well as the cultural, organizational, and financial conditions of the specific enterprise in order to be successful.

Since the situation of SMEs, and here particularly young enterprises, is often less proven and their strategies less explored over time, these tools will have to allow organizations to deal with external uncertainty and complexity enabling them to build their vision, and to find and expand their niche (while larger organizations rather need strategic tools to deal with their internal complexity). Therefore, it could be argued that there are several counteracting forces at work with respect to the need for strategic ('vision') management and ('bureaucratic') planning tools in the development from a small to a large enterprise: external uncertainty and complexity (usually) decreases, which requires less exploration and planning for alternative courses of action, while internal complexity increases and adaptability decreases, which requires more detailed planning of how to implement strategic actions. At the same time, uncertainty about the vision of an enterprise decreases. It could even be argued that young enterprises and SMEs practically engage in strategic management, while they lack bureaucratic implementation and control of the required measures, whereas larger, established organizations routinely implement planning and control, but lack agility, visionary impetus, and flexibility, which is why they need explicit strategic management tools.

Table 4 separates some of the relevant characteristics in a simplistic matrix. The differentiated consideration of these factors is even more important, as SMEs, in comparison to big companies, commonly boast a higher level of heterogeneity regarding size and development stage (Wirth, 1995). It can be seen that the enterprise characteristics differ significantly from the young and small venture compared to the established, large and old company (and the steps in between, i.e.: medium-sized and young, small and old, and medium-sized and old), and so do the strategic imperatives that can be concluded for each kind of enterprise respectively.
Table 4

Enterprise Characteristics and Strategic Planning vs. Management

\begin{tabular}{|l|c|c|}
\hline & $\begin{array}{c}\text { SMALL, } \\
\text { YOUNG }\end{array}$ & $\begin{array}{c}\text { ESTABLISHED, } \\
\text { LARGE, OLD }\end{array}$ \\
\hline Business model & Unproven & Proven \\
\hline Organization & Flexible & Inflexible \\
\hline Ressources & Scarce & Abundant \\
\hline Complexity & External & Internal \\
\hline Employees & Dedicated & Unmotivated \\
\hline Customers & Elusive & Captured \\
\hline $\begin{array}{l}\text { Strategic } \\
\text { imperative }\end{array}$ & $\begin{array}{c}\text { Learn, network and } \\
\text { prove yourself }\end{array}$ & $\begin{array}{c}\text { Differentiate and } \\
\text { defend }\end{array}$ \\
\hline DO & $\begin{array}{c}\text { Visionary Strategic } \\
\text { Management }\end{array}$ & $\begin{array}{c}\text { Strategic Planning } \\
\text { NEED }\end{array}$ \\
\hline & & $\begin{array}{c}\text { More) Visionary } \\
\text { Strategic } \\
\text { Management }\end{array}$ \\
\hline
\end{tabular}

The earlier notion that there are differences in strategic goals between small and bigger enterprises entails the need to also differentiate between the goals of different small enterprises. Generally speaking, goals depend on the situation of enterprises and their market niches. Within the scope of investigating SMEs' strategic instruments this should be considered. Likewise, a distinction between types of SMEs is clearly needed, at least in terms of age and market situation. While public interest mainly concentrates on SMEs as potential generators of growth, only a subset of these enterprises will essentially fulfil this role, thereby highlighting another differentiating factor.

Overall, it is plausible to assume that the problems of different SME types will vary. Thus, the procedural instructions and instruments for these enterprises will vary accordingly and have to be tailored to the individual case. This implies that there will also be differences in terms of necessary and/or suitable instruments of strategic planning and the resulting output. As a result, the measurable economic success of an enterprise and thus the correlation between economic success and the use of planning instruments will also depend on the particular type of enterprise. For example, considerable strategic differences exist between small, mature enterprises in a stable and specialized niche and young, growth-oriented enterprises. While the former aim at securing their market position, further developing their technology and closely satisfying their customers' needs in order to increase profits, young enterprises will - after testing the functional ca- 
pacity of their business model and their niche - shift their focus towards extending the market niche as well as their respective market share as soon as possible. This situation requires tools that focus much more on learning and sense-making (Weick, 1987) for small enterprises than they do for large ones. Particularly, young enterprises need to prove their vision correct or adapt it to changing conditions. It would be desirable, if these tools at the same time allowed easy implementation of the necessary planning activities integrated with 'vision development and testing'. The latter alone amounts to untangling a complex interrelated problem, that might be alleviated by a computerized tool for analysis.

Additionally, young enterprises have a strategic interest in demonstrating and actively communicating the value of their product and their approach in order to get access to possible customers. This is likely to encompass initial co-operation building with competitors in the same market niche in order to benefit on a larger scale through raising the awareness of customers and other stakeholders. Activities like forming associations or organizing conferences can serve as facilitators. After the market niche is established, a further development of the niche then enables a company to differentiate itself from its competitors (Henderson, 1989).

Applying economic reasoning to the question of why there is less planning in SMEs, different conclusions emerge: First, it can be argued that planning, in comparison to operational activities, results in less tangible outputs and is therefore discarded in SMEs. Also, psychological factors might play a role in that the bonus associated with operational activities is higher than for planning activities. Third, the pressure to address immediate problems and accomplish high-priority tasks might be so strong that planning activities are removed from the agenda.

\section{Conclusion and implications for future research}

The investigated empirical studies entail numerous limitations that need to be taken care of in future research. First, they are often limited to those enterprises that have already been identified as conducting strategic planning or to the surviving enterprises whereas failed companies are not considered ('survivor bias'). Moreover, the studies' response rate is usually small. Thus, it can also be assumed that questionnaires are mainly returned by those enterprises in which people do think and/or plan strategically. The derived share of use of strategic management instruments might therefore be artificially inflated. Furthermore, the aggregation of single functional plans was often already a sufficient condition for categorizing an SME as using strategic planning, which is of only little value.

Besides, the investigations are difficult to compare due to their differences in terms of enterprise type, industry, sample size, company size, or time period. Especially the term 'strategic planning' - which is a cornerstone for an entire discipline - exhibits only very little consistency in terms of its operationalization. The reason for this may be that many researchers focus on very specific within (Boyd - Reuning-Elliott, 1998).

Most analyzed studies furthermore only characterize enterprises either as planners or as non-planners. However, the presence of an elaborate planning system does not necessarily guarantee that this planning process will also be effective (Rhyne, 1986). The formal planning system is only one component in the strategy process. It seems unlikely that strategic thinking does only take place during the formal planning process.

Likewise, existent studies are often limited to one industry only, which reduces their potential to derive generalizable inferences. Thus, it would be interesting to examine whether there are differences in the degree of strategic planning with regard to industry affiliation. It is seems plausible to assume that in those industries, in which product development and order processing have a shorter time frame (e.g. in the services industry), or in those with a generally smaller range of products, less strategic planning occurs. Particularly for the German-speaking countries, a clear deficit can still be identified concerning strategy research in SMEs.

Investigations into the psychological nature of entrepreneurs and its relation to implementing strategic planning versus strategic management under different conditions of environmental and internal stress and the pressure of day-to-day activities seem highly desirable. This issue is related to the goals of the entrepreneur. Planning activities should be more prevalent and of higher quality, if the entrepreneur cares about his enterprise and does not 'just' become an entrepreneur to satisfy requirements for receiving subsidies or welfare programs. Bureaucratic planning and visionary strategic management seem to operate in different dimensions and seem to differ in terms of relative demand over the life cycle of an enterprise. The untangling of the different influences behind the characteristics mentioned in Table 4 requires further detailed investigation.

The dividing line between operational and strategic planning might become less visible when different types of companies are examined. It can be argued that enterprises of a relatively smaller size need to plan less 
strategically because they are more flexible and therefore can adapt much faster to changes in their immediate environment. This would entail differences in the time frames of strategic planning between SMEs and big companies.

Overall, it can be stated that there also seems to be a correlation between strategic planning and success in SMEs. Furthermore, scientific literature provides evidence that the use of strategic planning methods and instruments is dependent on increasing company size, and thus that SMEs do seem to plan less than established larger enterprises. Future studies should therefore address these restrictions and attempt to gain deeper insight into type, extent and alignment of strategic management instruments in SMEs as well as the resulting consequences for company success.

Our literature analysis indicates that strategic planning in SMEs is subject to unique characteristics and influences. Although a high relevance of strategic planning in the context of SME management does exist, its extent and design differs from bigger companies. Our base of operations presented in Figure 1 could thus be confirmed. Accordingly, research needs to devote more time to analyze the idiosyncrasies of this corporate sector in order to advance our understanding of strategic planning in SMEs and derive valuable recommendations for research and practice.

The results of this article provide some useful insights to owners and managers of SMEs. In that respect, we would like to conclude it with our own definition of strategic planning in SMEs, based on the results of previous literature that has been analyzed for this article. We for that reason follow the studies of McKiernan Morris (1994) and Armstrong (1982) on large-scale enterprises, which we have adapted to the small business context, as well as the study of Rue - Ibrahim (1998) on SMEs, and define strategic planning in SMEs according to the following set of criteria:

1) the setting of specific goals/the conception of specific strategies,

2) the planning ahead of future implications of current decisions (proactivity),

3) a time horizon of more than one year,

4) the development of possible alternative for goal achievement (scenarios),

5) a high degree of formality and high subjective importance of the concept of strategic planning,

6) the inclusion of the own strength/weaknesses in comparison to the competition as well as the chances/risks in the market (SWOT analysis),

7) the continuous monitoring/control (and if necessary revision of planning).

\section{Foot-notes}

${ }^{1}$ While it is the central construct of interest in much research on SMEs, it is often not clear what 'success' really means. Past empirical studies about strategic planning define success both with large enterprises (Rhyne, 1986) and with SMEs (Robinson, 1983; Gibson - Cassar - Wingham, 2001) usually on the basis of output-related financial characteristic numbers (profitability, turnover/profit growth, productivity, etc.). The authors follow this procedure and define the success of small enterprises in an enterprise-related context, i.e. in terms of financial numbers. The term 'success' is thus being used synonymously to 'performance' in this article.

2 According to Katz (1999), these journals make up the "Big 4" in Entrepreneurship research.

${ }^{3}$ For this purpose, the library of the University of Cologne, Germany's largest university, as well as the university libraries in Oldenburg, Germany, and Klagenfurt, Austria have been used. Additional sources which could not be obtained, have been borrowed by interlending procedures from other German libraries.

\section{References}

Bauer, B. (2002): Kleine und mittlere Unternehmen - Übersicht über Bedeutung, bereits getroffene und mögliche weitere Maßnahmen auf EU-Ebene und in Österreich. Vienna: Bundesministerium für Finanzen

Berman, J.A. - Gordon, D. D. - Sussmann, G. (1997): A study to determine the benefits small business firms derive from sophisticated planning versus less sophisticated types of planning. Journal of Business and Economic Studies, 3(3): pp. 1-11.

Beutel, R. (1988): Unternehmensstrategien international tätiger mittelständischer Unternehmen. Frankfurt am Main: Lang

Boyd, B.K. - Reuning-Elliott, E. (1998): Research notes and communications - a measurement model of strategic planning. Strategic Management Journal, 19: pp.181-192.

Bracker, J.S. - Keats, B. W. - Pearson, J. N. (1988): Planning and financial performance among small firms in a growth industry. Strategic Management Journal, 9(6): pp. 591-603.

Bracker, J.S. - Pearson, J. N. (1986): Planning and financial performance of small mature firms. Strategic Management Journal, 7(6): pp. 503-522.

Carland, J.W. - Carland, J.A.C. - Aby, C.D. (1989): An assessment of the psychological determinants of planning in small businesses. International Small Business Journal, 7(4): pp. 23-34.

Castrogiovanni, G.J. (1996): Pre-startup planning and the survival of new small businesses: Theoretical linkages. Journal of Management, 22(6): pp. 801-822.

Cooper, A.C. (1981): Strategic management: new ventures and small business. Long Range Planning, 14: pp.39-45.

Delmar, F. - Shane, S. (2003): Does business planning facilitate the development of new ventures? Strategic Management Journal, 24(12): pp. 1165-1185.

Duchesneau, D.A. - Gartner, W.B. (1990):): A profile of new venture success and failure in an emerging industry. Journal of Business Venturing, 5: pp. 297-312. 
EU Commission (2003). SME definition: Commission Recommendation of 06 May 2003. Brussels: European Commission

Esser, W.M. - Höfner, K. - Kirsch, W. - Wieselhuber, N. (1985): Der Stand der strategischen Unternehmensführung in der Bundesrepublik Deutschland und West-Berlin. In W. Trux et al. (Eds.), Das Management strategischer Programme, vol. 2: pp. 495-568.

Foster, R.N. ((1986):): Innovation: The attacker's advantage. New York: Summit Books

Fröhlich, E. - Pichler, J.H. (1988): Werte und Typen mittelständischer Unternehmer. Berlin: Duncker - Humblot

Füglistaller, U. - Frey, U. - Halter, F. (2003): Strategisches Management für KMU - Eine praxisorientierte Anleitung. St. Gallen: KMU HSG

Gibb, A. - Scott, M. (1985): Strategic awareness, personal commitment and the process of planning in the small business. Journal of Management Studies, 22(6): pp. 597-630.

Gibson, B. - Cassar, G. - Wingham, D. (2001):): Longitudinal analysis of relationships between planning and performance in small Australian firms. Proceedings of the USASBE/SBIDA Annual National Conference, Orlando, FL, 2001: pp. 1-22.

Gibson, B. - Cassar, G. (2002): Planning behavior variables in small firms. Journal of Small Business Management, 40(3): pp. 171-186.

Gray, C. (1992): Growth-orientation and the small firm. In K. Caley (Ed.), Small Enterprise Development. London: Chapman, pp. 59-71.

Haake, K. (1987): Strategisches Verhalten in europäischen Kleinund Mittelunternehmen. Berlin: Duncker - Humblot.

Henderson, B.D. (1989): The Origin of Strategy. Harvard Business Review, 67(6): pp. 139-143.

Ibrahim, A.B. (1993): Strategy types and small firms' performance: An empirical investigation. Journal of Small Business Strategy, 4: pp. 13-22.

Johnson, G. - Scholes, K. (1997): Exploring corporate strategy (4th ed.). London: Prentice Hall

Karagozoglu, N. - Lindell, M. (1998): Internationalization of small and medium-sized technology-based firms: An exploratory study. Journal of Small Business Management, 36(1): pp. 44-59.

Kraus, S. (2006): Strategische Planung und Erfolg junger Unternehmen. Wiesbaden: Gabler

Kraus, S. - Málovics, E. - Málovics, G. (2005): Strategic Planning in Smaller Enterprises - Does it really make sense?, In L.A. Toombs, L.A. (Ed.), The Changing Entrepreneurial Landscape, Madison, WI: USASBE, pp. 1-8.

Kreikebaum, H. (1993): Strategische Unternehmensplanung (5th ed.). Berlin: Kohlhammer

Kropfberger,D.(1986):ErfolgsmanagementstattKrisenmanagement - Strategisches Management in Mittelbetrieben. Linz: Trauner

Küpper, H. U. - Bronner, T. (1995): Strategische Ausrichtung mittelständischer Unternehmungen. Internationales Gewerbearchiv, 43: pp. 73-87.
Leitner, K.H. (2001): Strategisches Verhalten von kleinen und mittleren Unternehmungen. Unpublished doctoral dissertation, University of Vienna, Austria

Lussier, R.N. - Pfeifer, S. (2000): A comparison of business success versus failure variables between U.S. and Central Eastern Europe Croatian entrepreneurs. Entrepreneurship: Theory - Practice, 24, pp. 59-67.

Lyles, M.A. - Baird, I.S. - Orris, J.B. - Kuratko, D.F. (1993): Formalized planning in small business: Increasing strategic choices. Journal of Small Business Management, 31(2): pp. 38-50.

Martin, J. (1979): Business planning: The gap between theory and practice. Long Range Planning, 12: pp. 2-10.

Matthews, C.H. - Scott, S.G. (1995): Uncertainty and planning in small and entrepreneurial firms: An empirical assessment. Journal of Small Business Management, 33(4): pp. 34-52.

Mazzarol, T. (2003): The strategic management of small firms: Does the theory fit the practice? University of Western Australia Discussion Paper, No. 0301.

McCarthy, B. (2003): The impact of the entrepreneur's personality on the strategy-formation and planning process in SMEs. Irish Journal of Management, 24: pp. 154-172.

Mintzberg, H. (1994): The fall and rise of strategic planning. Harvard Business Review, 72(1): pp. 107-114.

Naffziger, D.W. - Kuratko, D.F. (1991): An investigation into the prevalence of planning in small business. Journal of Business and Entrepreneurship, 3(2): pp. 99-110.

Naffziger, D.W. - Mueller, C. (1999): Strategic planning in small businesses: Process and content realities. Proceedings of the USASBE/SBIDA Annual National Conference: pp. 1-15.

Noteboom, B. (1994): Innovation and diffusion in small firm: Theory and evidence. Small Business Economics, 6: pp. 327-347.

Ohmae, K. (1982): The mind of the strategist - The art of Japanese business. New York: McGraw-Hill

Olson, P.D. - Bokor, D.W. (1995): Strategy process-content interaction: Effects on growth performance in small startup firms. Journal of Small Business Management, 33(1): pp. 34-44.

Orpen, C. (1985): The effects of long-range planning on small business performance: A further examination. Journal of Small Business Management, 23(1): pp. 16-23.

Pasanen, M. (2003): In search of factors affecting SME performance: the case of Eastern Finland. Kuopio: University Publications

Piest, B. (1994): Planning comprehensiveness and strategy in SMEs. Small Business Economics, 6(5): pp. 387-395.

Pleitner, H. J. (1986): Strategisches Verhalten mittelständischer Unternehmen. Internationales Gewerbearchiv, 34: pp.159-171.

Porter, M.E. (1983): Wettbewerbsstrategie. Frankfurt: Campus

Reschke, C.H. - Kraus, S. (2005): Strategy and strategic management as process of social evolution - an 
introductory overview over relevant perspectives, Paper presented at the BAM Conference 2005, Oxford

Rhyne, L.C (1986): The relationship of strategic planning to financial performance. Strategic Management Journal, 7: pp. 423-437.

Riquelme, H. (2000): How to develop more creative strategic plans: Results from an empirical study. Creativity and Innovation Management, 9: pp. 14-20.

Risseeuw, P. - Masurel, E. (1994): The role of planning in small firms: Empirical evidence from a service industry. Small Business Economics, 6: pp. 313-322.

Robinson, R.B. (1983): Measures of small firm effectiveness for strategic planning research. Journal of Small Business Management, 21: pp. 22-29.

Robinson, R.B. - Pearce, J. A. (1983): The impact of planning on financial performance in small organizations. Strategic Management Journal, 4(3): pp. 197-207.

Robinson, R.B. - Pearce, J.A. (1984): Research thrusts in small firm strategic planning. Academy of Management Review, 9(1): pp. 128-137.

Robinson, R.B. - Pearce, J.A. - Vozikis, G.S. - Mescon, T.S. (1984): The relationship between stage of development and small firm planning and performance. Journal of Small Business Management, 22(2): pp. 45-52.

Robinson, R.B. - Logan, J.E. - Salem, M.Y. (1986): Strategic versus operational planning in small retail firms. American Journal of Small Business, 10: pp. 7-16.

Rue, L.W. - Ibrahim, N.A. (1998): The relationship between planning sophistication and performance in small businesses. Journal of Small Business Management, 36(4): pp. 24-32.

Scharpe, J. (1992): Strategisches Management im Mittelstand: Probleme der Implementierung und Ansätze zur Lösung. Köln: Eul.

Scholz, L. (1991): Strategische Unternehmensplanung in der deutschen Industrie: Bestandsaufnahme und kritische Bewertung. ifo Schnelldienst, 44(11): pp. 17-25.

Schumpeter, J. (1934): The theory of economic development. Cambridge: Harvard University Press
Schwenk, C.R. - Shrader, C.B. (1993): Effects of formal strategic planning on financial performance in small firms: A meta-analysis. Entrepreneurship: Theory and Practice, 17(3): pp. 53-64.

Seibert, S. (1987): Strategische Erfolgsfaktoren in mittleren Unternehmen: Untersucht am Beispiel der Fördertechnikindustrie. Frankfurt am Main: Lang

Sexton, D.K. - Van Auken, P. (1982): Prevalence of strategic planning in small business. Journal of Small Business Management, 20(1): pp. 20-26.

Sexton, D.K. - Van Auken, P. (1985): A longitudinal study of small business strategic planning. Journal of Small Business Management, 23(1): pp. 7-15.

Shuman, J.C. - Seeger, J.A. (1986): The theory and practice of strategic management in smaller rapid growth firms. American Journal of Small Business, 11(1): pp. 7-18.

Simon, H. (1996): Hidden champions: Lessons from 500 of the World's best unknown companies. Boston, MA: Harvard Business School Press

van Horn, T.P. (1979): Strategic planning in small and mediumsized companies. Long Range Planning, 2: pp. 84-91.

Vesper, K.H. (1980): New venture planning. Journal of Business Strategy, 1: pp. 73-75.

Voigt, K.I. (1992): Strategische Planung und Unsicherheit. Wiesbaden: Gabler

Weick, K.E. (1987): Substitutes for Strategy. In D.T. Teece (Ed.), Competitive Challenge Strategies for Industrial Innovation and Renewal. Cambridge: Ballinger, pp. 221-233.

Welter, F. (2003): Strategien, KMU und Umfeld Handlungsmuster und Strategiegenese in kleinen und mittleren Unternehmen. Berlin: Duncker - Humblot

Wirth, B. (1995): Strategieberatung von Klein- und Mittelunternehmen - ein umfassendes Konzept zur Unterstützung von KMU bei der strategischen Führung. Hallstadt:Rosch-Busch

Cikk beérkezett: 2006. 5. hó

Lektori vélemény alapján átdolgozva: 2007. 2. hó 